\title{
Prognostic Impact of Factor V Leiden in Systemic Lupus Erythematosus Pediatric Patients
}

\author{
${ }^{1}$ Sahar S. Abd Elmaksoud, ${ }^{1}$ Doaa A.G. Eissa, ${ }^{2}$ Hanan M. Abd El Lateef, \\ ${ }^{1}$ Noha S.A. Abdelhalim \\ ${ }^{1}$ Department of Clinical Pathology, ${ }^{2}$ Department of Pediatric Immunology, Ain Shams University \\ Corresponding author: Noha S.A. Abdelhalim, Mobile: 01091275975, E-mail: dr.nohasalaheldin2016@gmail.com
}

\begin{abstract}
Objective: This research aimed to study the presence of factor V gene G1691A mutation (Factor V Leiden) in SLE pediatric patients with and without complications and to investigate the association between the presence of Factor V Leiden and lupus complications mainly lupus nephiritis in these patients.

Subjects and Methods: This study was conducted on 50 Egyptian pediatric patients (48 females and 2 males) who were all diagnosed as SLE according to the American College of Rheumatology criteria. They were enrolled from the Immunological Clinics at Ain shams University Pediatric Hospital and were divided into two groups: Group 1 (control group) of matched age and sex: Including 25 newly diagnosed uncomplicated SLE patients e.g.: arthritis, musculoskeletal and cutaneous lupus. Group 2 (patients group): Including 25 SLE complicated patient e.g.: nephritis, neurolupus, thrombotic manifestation, cardities and antiphospholipid antibody syndrome. The complications observed in patient group was further classified into lupus nephritis alone or lupus nephritis with other complications (21 patients) or patients with complications other than lupus nephritis (4 patients).

Results: All patients included in this study were subjected after taking their parents' consent to full history taking laying stress on history of complications mainly lupus nephritis. In addition, laboratory investigations which include CBC, tests for confirmation of SLE as ANA, anti dsDNA, C3, lupus anticoagulant, anticardiolipin $\operatorname{IgG}$ and $\operatorname{IgM}$ and renal function tests as serum creatinine and $24 \mathrm{hrs}$ urinary proteinsm were done. The Factor V gene mutation was determined by the method of PCR-based DNA analysis in both control and patient groups. In control group, there was 1 out of 25 patients having the Factor V Leiden mutation; who had a heterozygous pattern. The prevalence of Factor V Leiden in patients group showed 2 out of 25 patients, both of them had a heterozygous pattern of the gene mutation.

Conclusion: This study couldn't demonstrate any correlation between the presence of Factor V Leiden mutation and the presence of complications in SLE patients as there was no statistical significant difference (P $>0.05$ ).
\end{abstract}

Keywords: Systemic Lupus Erythematosus - Factor V Leiden - Activated Protein C resistance

\section{INTRODUCTION}

Systemic Lupus Erythematosus (SLE) is a chronic autoimmune inflammatory disease that has a highly variable course of relapsing and remitting, resulting in damage to essentially any organ system. Ninety percent of SLE cases occur in females, frequently starting at child bearing age ${ }^{(I)}$. They are affected about nine times more than men ${ }^{(2)}$.

The diagnosis of SLE is often complex combining between both clinical and laboratory criteria. It's based on the presence of 4 out of 11 of the American College of Rheumatology (ACR) criteria for the classification of SLE ${ }^{(3)}$. These criteria include serositis, oral ulcers, arthritis, photosensitivity, blood disorders, renal involvement, antinuclear antibodies, immunological phenomena, neurological disorders, malar rash and discoid rash ${ }^{(4,5)}$.

Children diagnosed with SLE may be complicated with infections, hematological abnormalities, renal manifestations, neurological manifestations, pulmonary manifestations, gastrointestinal manifestations and cardiac manifestations. Thrombotic complications are frequently observed in SLE especially during active lupus with vasculitis ${ }^{(6)}$.

According to some authors, thrombotic and cardiovascular are the first complications of SLE after flares of the disease ${ }^{(7)}$. SLE has been widely described as independent risk factor itself for developing arterial and venous thrombosis with a prevalence $>10 \%$. This prevalence may even exceed $50 \%$ in high-risk patients ${ }^{(8)}$. The incidence of thrombosis increased in the first year. Possible reasons for this early higher incidence of thrombosis could be the high levels of disease activity and circulating immune complexes, cytotoxic antibodies, or a higher inflammatory state ${ }^{(9)}$. Thrombotic risk also increases in the presence of inherited or acquired prothrombotic abnormalities or of triggering events such as infections ${ }^{(10)}$.

Factor V Leiden (FVL) is considered as the most common cause for venous thrombosis in SLE 
and inherited thrombophilia. It is the most thrombotic risk factor known in Caucasians (around 5\%) ${ }^{(11)}$.

FVL is an autosomal dominant inherited defect caused by a single specific point mutation in the FV gene, which is located in the long arm of chromosome 1 , resulting in a guanine to adenine substitution at nucleotide position 1691. This mutation alters the activated protein $\mathrm{C}$ (APC) cleavage site on $\mathrm{FV}$, causing resistance to APC, shifting the balance towards thrombosis ${ }^{(12)}$. About $20-60 \%$ of patients with thromboembolism have a form of APC resistance, and FV Leiden is responsible for $95 \%$ of APC resistance ${ }^{(13)}$.

\section{AIM OF THE WORK}

We aimed to study the presence of factor $\mathrm{V}$ Leiden in SLE pediatric patients with and without complications. In addition to investigate the association between the presence of factor $\mathrm{V}$ Leiden and lupus complications in SLE pediatric patients.

\section{PATIENTS AND METHODS}

Subjects: This study was carried out in Pediatric Educational Hospital of Ain Shams University. The study group included 50 children patients diagnosed as SLE according to the American College of Rheumatology criteria (ARC) ${ }^{(3)}$ who were attending the Immunology Clinics at Ain Shams University Pediatric Hospital between the period from December 2016 up to June 2017.

The study was approved by the Ethics Board of Ain Shams University.

They were divided into two groups: Group 1(control group): Includes 25 newly diagnosed uncomplicated SLE patients e.g.: arthritis, musculoskeletal and cutaneous lupus. Group 2 (patients group): Included 25 SLE complicated patient e.g.: nephritis, neurolupus, thrombotic manifestation, cardities and antiphospholipid antibody syndrome.

All individuals included in this study were subjected to full history taking after gaing their parents' consent: Full history taking. History of complications mainly Lupus nephritis. Laboratory investigations which included: Complete blood count (CBC) using Coulter Gen S system 2 (Beckman), tests for confirmation of SLE as ANA, anti dsDNA. Complement 3 (C3), lupus anticoagulant, anticardiolipin $\operatorname{IgG}$ and $\operatorname{IgM}$ and renal function tests as serum creatinine and $24 \mathrm{hrs}$ urinary proteins. Additionally, laboratory investigations to diagnose the presence of the thrombophilic defects by DNA analysis of inherited thrombophilic genes (Factor V Leiden) using polymerase chain reaction (PCR) were done.

Methods: PCR detection of FVL mutation(Arg1691Gln).

Statistical methodology: Data analysis was done using Statistics Package for the Social Science (SPSS Inc., Chicago, IL, USA version 20).

I) Statistical tests used in the study were: Results of descriptive statistics were presented as mean \pm standard deviation or median. Results of categorical variables were presented as number and percentage. Comparison between categorical (qualitative) variables was performed using Chi-square $\left(\mathrm{x}^{2}\right)$ or Fisher's exact test. Comparison between quantitative variables was carried out performed using t-test $(t)$ for independent sample means

II) Significance level (P value) was expressed as follows: $\mathrm{P}$ value $<0.05$ was used as a cut off value for significance: $P$ value $>0.05$ is non-significant (NS). P value $<0.05$ is significant $(\mathrm{S})$. $\mathrm{P}$ value $<0.01$ is highly significant (HS).

\section{RESULTS}

Table (1): Complications observed in patients' group.

\begin{tabular}{|l|c|c|}
\hline \multicolumn{1}{|c|}{ Parameter } & N & \% \\
\hline LN alone & 10 & 40 \\
\hline LN with complications & 11 & 44 \\
\hline Other than LN & 4 & 16 \\
\hline Total & 25 & 100 \\
\hline
\end{tabular}

LN: Lupus nephritis

The complications observed in patients' group were further subclassified into

lupus nephritis alone (10 patients representing $40 \%$ ), lupus nephritis with complications (11 patients representing 44\%) and complications other than lupus nephritis (4 patients representing 16\%).

Table (2): Comparison between control group and patients' group regarding to Demographic data.

\begin{tabular}{|c|c|c|c|c|c|c|c|}
\hline Parameter & \multicolumn{2}{|c|}{$\begin{array}{c}\text { Control } \\
n=25\end{array}$} & \multicolumn{2}{|c|}{$\begin{array}{c}\text { Patients } \\
n=25\end{array}$} & $\begin{array}{c}\text { Test of } \\
\text { significance }\end{array}$ & $\begin{array}{c}\mathbf{P} \\
\text { value }\end{array}$ & Significance \\
\hline $\begin{array}{l}\text { Age (years) } \\
\text { Mean + SD }\end{array}$ & \multicolumn{2}{|c|}{$14.68+2.11$} & \multicolumn{2}{|c|}{$13.88+1.9$} & $\mathrm{t}=-1.40$ & 0.16 & NS \\
\hline $\begin{array}{l}\text { Gender } \\
\text { Male n(\%) } \\
\text { Female n(\%) }\end{array}$ & $\begin{array}{c}1 \\
24 \\
\end{array}$ & $\begin{array}{c}4 \\
96 \\
\end{array}$ & $\begin{array}{c}1 \\
24 \\
\end{array}$ & $\begin{array}{c}4 \\
96 \\
\end{array}$ & $\mathrm{x} 2=0.00 *$ & 1.00 & NS \\
\hline $\begin{array}{l}\text { Consanguinity } \\
\text { Positive } \mathrm{n}(\%) \\
\text { Negative } \mathrm{n}(\%)\end{array}$ & $\begin{array}{c}2 \\
23\end{array}$ & $\begin{array}{c}8 \\
92\end{array}$ & $\begin{array}{c}8 \\
17 \\
\end{array}$ & $\begin{array}{l}32 \\
68\end{array}$ & $\mathrm{x} 2=4.50$ & 0.03 & S \\
\hline $\begin{array}{l}\text { Family history } \\
\text { Positive } \mathrm{n}(\%) \\
\text { Negative } \mathrm{n}(\%)\end{array}$ & $\begin{array}{c}4 \\
21\end{array}$ & $\begin{array}{l}16 \\
84\end{array}$ & $\begin{array}{c}9 \\
16\end{array}$ & $\begin{array}{l}36 \\
64\end{array}$ & $\mathrm{x} 2=2.59$ & 0.10 & NS \\
\hline
\end{tabular}

*Fisher Exact test 
On comparing between control group and patients' group regarding demographic data, there was a statistical significant difference regarding consanguinity between parents $(\mathrm{P}=0.03)$. No statistical significant difference was detected between both groups regarding age, gender and family history of similar or other autoimmune diseases $(\mathrm{P}>0.05)$.

Table (3): Comparison between control group and patients' group regarding hematological data.

\begin{tabular}{|l|c|c|c|c|c|}
\hline Parameter & $\begin{array}{c}\text { Control } \\
\mathbf{n}=\mathbf{2 5}\end{array}$ & $\begin{array}{c}\text { Patients } \\
\mathbf{n}=\mathbf{2 5}\end{array}$ & $\mathbf{t}-$ Test & $\begin{array}{c}\mathbf{P} \\
\text { value }\end{array}$ & Significance \\
\hline $\mathrm{Hb}(\mathrm{g} / \mathrm{dl})$ & $11.52+1.64$ & $11.30+1.36$ & $\mathrm{t}=0.50$ & 0.61 & $\mathrm{NS}$ \\
\hline $\begin{array}{l}\text { TLC } \\
(\mathrm{x} 109 / \mathrm{L})\end{array}$ & $10.14+2.63$ & $8.86+4.25$ & $\mathrm{t}=1.27$ & 0.20 & $\mathrm{NS}$ \\
\hline $\begin{array}{l}\mathrm{PLT} \\
(\mathrm{x} 109 / \mathrm{L})\end{array}$ & $273.9+120.2$ & $246.8+106.3$ & $\mathrm{t}=0.84$ & 0.40 & $\mathrm{NS}$ \\
\hline $\begin{array}{l}\mathrm{ESR} \\
(\mathrm{mm} / \mathrm{hr})\end{array}$ & $22.16+12.15$ & $23.32+10.02$ & $\mathrm{t}=-0.36$ & 0.71 & $\mathrm{NS}$ \\
\hline
\end{tabular}

On comparing between control and patients' groups regarding hematological data; no statistical significant difference was detected regarding hemoglobin, total leucocytic count, platelet count and ESR $(\mathrm{P}>0.05)$.

Table (4): Comparison between control group and patients' group regarding immunological data.

\begin{tabular}{|l|c|c|c|c|c|}
\hline \multicolumn{1}{|c|}{ Parameter } & $\begin{array}{c}\text { Control } \\
\mathbf{n}=\mathbf{2 5}\end{array}$ & $\begin{array}{c}\text { Patients } \\
\mathbf{n = 2 5}\end{array}$ & $\mathbf{t}$-Test & P value & Significance \\
\hline $\begin{array}{l}\mathrm{C} 3 \\
(\mathrm{mg} / \mathrm{dl})\end{array}$ & $86.60+40.06$ & $87.72+37.18$ & $\mathrm{t}=-0.10$ & 0.91 & $\mathrm{NS}$ \\
\hline $\begin{array}{l}\text { IgG } \\
(\mathrm{GPLU} / \mathrm{ml})\end{array}$ & $8.91+3.68$ & $17.92+19.15$ & $\mathrm{t}=-2.31$ & 0.02 & $\mathrm{~S}$ \\
\hline $\begin{array}{l}\text { IgM } \\
(\mathrm{MPLU} / \mathrm{ml})\end{array}$ & $6.19+3.34$ & $14.3+14.4$ & $\mathrm{t}=-2.75$ & 0.01 & $\mathrm{~S}$ \\
\hline $\begin{array}{l}\text { Lupus } \\
\text { anticoagulant }\end{array}$ & $35.78+6.29$ & $45.18+23.02$ & $\mathrm{t}=-1.96$ & 0.05 & $\mathrm{~S}$ \\
\hline
\end{tabular}

GPLU $=\mathrm{G}$ phospholipids unit

MPLU $=\mathrm{M}$ phospholipids unit

All individuals at the time of sample collection in both patients' and control groups have both ANA positive and anti dsDNA positive. On comparing between patients' and control groups regarding further immunological data; anti cardiolipin IgG and IgM, as well as lupus anticoagulant showed a statistical significant difference $(\mathrm{P}=0.02,0.01,0.05)$ respectively. No statistical significant difference was detected between both groups regarding $\mathrm{C} 3(\mathrm{P}=0.91)$.

Table (5): Comparison between control group and patients' group regarding biochemical data.

\begin{tabular}{|l|c|c|c|c|c|}
\hline \multicolumn{1}{|c|}{ Parameter } & $\begin{array}{c}\text { Control } \\
\mathbf{n = 2 5}\end{array}$ & $\begin{array}{c}\text { Patients } \\
\mathbf{n = 2 5}\end{array}$ & $\mathbf{t}$-Test & P value & Significance \\
\hline $\begin{array}{l}\text { S. creatinine } \\
(\mathrm{mg} / \mathrm{dl})\end{array}$ & $0.49+0.14$ & $0.61+0.24$ & $\mathrm{t}=-2.09$ & 0.04 & $\mathrm{~S}$ \\
\hline BUN $(\mathrm{mg} / \mathrm{dl})$ & $11.08+2.15$ & $13.84+5.92$ & $\mathrm{t}=-2.19$ & 0.03 & $\mathrm{~S}$ \\
\hline $\begin{array}{l}24 \mathrm{hrs} \text { urine proteins } \\
(\mathrm{mg} / 24 \mathrm{hrs})\end{array}$ & $74.0+28.0$ & $438+510$ & $\mathrm{t}=-3.55$ & 0.00 & $\mathrm{HS}$ \\
\hline
\end{tabular}

The comparison between patients' and control group regarding biochemical data including serum creatinine level, BUN and $24 \mathrm{hrs}$ urinary protein showed a statistical significant difference $(\mathrm{P}=$ $0.04,0.03,0.00)$ respectively.

Table (6): Comparison between control group and patients' group regarding FVL mutation.

\begin{tabular}{|c|c|c|c|c|c|c|c|}
\hline \multirow[b]{2}{*}{ Parameter } & \multicolumn{4}{|c|}{ Group } & \multirow[b]{2}{*}{$\begin{array}{l}\text { Chi- } \\
\text { square }\end{array}$} & \multirow[b]{2}{*}{$\begin{array}{c}\mathbf{P} \\
\text { value }\end{array}$} & \multirow[b]{2}{*}{ Significance } \\
\hline & & & $\begin{array}{r}\text { Pat } \\
\mathbf{n}=\end{array}$ & $\begin{array}{l}\text { ents } \\
25\end{array}$ & & & \\
\hline $\begin{array}{l}\text { FVL } \\
\text { mutation } \\
\text { Normal } \\
\text { pattern } n(\%) \\
\text { Heterozygous } \\
\text { pattern } n(\%)\end{array}$ & $\begin{array}{c}24 \\
1\end{array}$ & $\begin{array}{c}96 \\
4\end{array}$ & $\begin{array}{c}23 \\
2\end{array}$ & $\begin{array}{c}92 \\
8\end{array}$ & $x 2=0.35^{*}$ & 1.00 & NS \\
\hline
\end{tabular}

$\mathrm{FVL}=$ Factor $\mathrm{V}$ Leiden

*Fisher Exact test

On comparing between patients' and control groups regarding FVL mutation ; no statistical significant difference was detected. $(\mathrm{P}=1.00)$.

Table (7): Comparison between FVL mutation and hematological data:

\begin{tabular}{|c|c|c|c|c|c|}
\hline \multirow[b]{2}{*}{ Parameter } & \multicolumn{2}{|c|}{ FVL } & \multirow[b]{2}{*}{ t-Test } & \multirow[b]{2}{*}{$P$ value } & \multirow[b]{2}{*}{ Significance } \\
\hline & $\begin{array}{l}\text { Normal } \\
\text { pattern }\end{array}$ & \begin{tabular}{|c} 
Hetero- \\
-zygous \\
pattern
\end{tabular} & & & \\
\hline $\mathrm{Hb}(\mathrm{g} / \mathrm{dl})$ & $11.40+1.52$ & $11.50+1.25$ & $t=-0.104$ & 0.91 & NS \\
\hline $\begin{array}{l}\text { TLC } \\
(\mathrm{x} 109 / \mathrm{L})\end{array}$ & $9.23+2.47$ & $13.63+2.28$ & $\mathrm{t}=-2.14$ & 0.03 & S \\
\hline $\begin{array}{l}\text { PLT } \\
(x 109 / L)\end{array}$ & $268.9+11.3$ & $126.6+7.63$ & $\mathrm{t}=8.45$ & 0.00 & HS \\
\hline $\begin{array}{l}\text { ESR } \\
(\mathrm{mm} / \mathrm{hr})\end{array}$ & $22.49+7.27$ & $26.67+2.07$ & $t=-0.31$ & 0.78 & NS \\
\hline
\end{tabular}

On comparing between FVL mutation results among patients' and control groups regarding hematological data ; total leucocytic count showed a statistical significant difference (P 0.03) and platelet count showed a highly statistical significant difference $(P=0.00)$. Both hemoglobin and ESR showed no statistical significant difference when compared between FVL results among both groups $(\mathrm{P}>0.05)$.

Table (8): Comparison between FVL mutation and immunological data.

\begin{tabular}{|c|c|c|c|c|c|}
\hline \multirow[b]{2}{*}{ Parameter } & \multicolumn{2}{|c|}{ FVL } & \multirow[b]{2}{*}{ t-Test } & \multirow[b]{2}{*}{$P$ value } & \multirow[b]{2}{*}{ Significance } \\
\hline & $\begin{array}{l}\text { Normal } \\
\text { pattern }\end{array}$ & $\begin{array}{l}\text { Hetero- } \\
\text {-zygous } \\
\text { pattern }\end{array}$ & & & \\
\hline C3 (mg/dl) & $88.64+38.25$ & $64.00+36.75$ & $\mathrm{t}=1.08$ & 0.28 & NS \\
\hline $\operatorname{IgG}(\mathrm{GPLU} / \mathrm{ml})$ & $13.71+14.80$ & $8.86+1.96$ & $t=0.56$ & 0.57 & NS \\
\hline IgM (MPLU/ml) & $10.63+11.37$ & $4.43+2.08$ & $t=0.93$ & 0.35 & $\mathrm{NS}$ \\
\hline $\begin{array}{l}\text { Lupus } \\
\text { anticoagulant }\end{array}$ & $40.57+17.87$ & $39.03+6.00$ & $\mathrm{t}=0.14$ & 0.88 & NS \\
\hline
\end{tabular}

GPLU $=\mathrm{G}$ phospholipids unit

$\mathrm{MPLU}=\mathrm{M}$ phospholipids unit

On comparing between FVL mutation results among patients' and control groups regarding 
immunological data; no statistical significance difference was detected. $(\mathrm{P}>0.05)$.

Table (9): Comparison between FVL mutation and biochemical data.

\begin{tabular}{|c|c|c|c|c|c|}
\hline \multirow[b]{2}{*}{ Parameter } & \multicolumn{2}{|c|}{ FVL } & \multirow[b]{2}{*}{ t-Test } & \multirow[b]{2}{*}{$\begin{array}{c}P \\
\text { value }\end{array}$} & \multirow[b]{2}{*}{ Significance } \\
\hline & $\begin{array}{l}\text { Normal } \\
\text { pattern }\end{array}$ & \begin{tabular}{|c|} 
Hetero- \\
-zygous \\
pattern \\
\end{tabular} & & & \\
\hline $\begin{array}{l}\text { S. creatinine } \\
(\mathrm{mg} / \mathrm{dl})\end{array}$ & $0.559+0.13$ & $0.433+0.057$ & $\mathrm{t}=2.76$ & 0.02 & S \\
\hline BUN (mg/dl) & $12.40+4.59$ & $13.33+2.11$ & $\mathrm{t}=-0.33$ & 0.74 & NS \\
\hline $\begin{array}{l}24 \mathrm{hrs} \text { urine } \\
\text { proteins } \\
\text { (mg/24hrs) }\end{array}$ & $250.0+40.0$ & $346.0+38.0$ & $t=-0.39$ & 0.69 & NS \\
\hline
\end{tabular}

On comparing between FVL results and biochemical data among patients' and control groups; serum creatinine level showed a statistical significant difference $(\mathrm{P}=0.02)$. Both BUN and 24hrs urinary proteins showed non statistical significant difference $(\mathrm{P}>0.05)$.

Table (10): Comparison between FVL mutation and complicated SLE patients (group 2).

\begin{tabular}{|c|c|c|c|c|c|c|c|}
\hline \multirow{3}{*}{\begin{tabular}{|r|} 
Parameter \\
LN only n $(\%)$ \\
\end{tabular}} & \multicolumn{4}{|c|}{ FVL } & \multirow[b]{2}{*}{ Chi-square } & \multirow[b]{2}{*}{$\begin{array}{c}\mathbf{P} \\
\text { value }\end{array}$} & \multirow[b]{2}{*}{ Significance } \\
\hline & \multicolumn{2}{|c|}{$\begin{array}{l}\text { Normal } \\
\text { pattern }\end{array}$} & \multicolumn{2}{|c|}{$\begin{array}{l}\text { Hetero- } \\
\text {-zygote } \\
\text { pattern }\end{array}$} & & & \\
\hline & 10 & 43.5 & 0 & 0 & & & \\
\hline $\begin{array}{l}\mathrm{LN} \text { and other } \\
\text { complications } \\
\mathrm{n}(\%)\end{array}$ & 9 & 39.1 & 2 & 100 & & & \\
\hline $\begin{array}{l}\text { Complications } \\
\text { other than LN } \\
\mathrm{n}(\%)\end{array}$ & 4 & 17.4 & 0 & 0 & $\mathrm{X} 2=2.06^{*}$ & 0.633 & NS \\
\hline Total n(\%) & 23 & 100 & 2 & 100 & & & \\
\hline
\end{tabular}

LN: lupus nephritis

*Fisher Exact test

On comparing between FVL mutation results and SLE patients with complications, no statistical significant difference was detected. $(\mathrm{P}>0.05)$

Table (11): Comparison between FVL mutation and response of therapy in $\mathrm{LN}$ patients.

\begin{tabular}{|c|c|c|c|c|c|c|c|}
\hline \multirow{3}{*}{$\begin{array}{l}\text { Parameter } \\
\text { Good response } \\
\text { n(\%) }\end{array}$} & \multicolumn{4}{|c|}{ FVL } & \multirow[b]{2}{*}{$\begin{array}{c}\text { Chi- } \\
\text { square }\end{array}$} & \multirow[b]{2}{*}{$\begin{array}{c}P \\
\text { value }\end{array}$} & \multirow[b]{2}{*}{ Significance } \\
\hline & \multicolumn{2}{|c|}{$\begin{array}{l}\text { Normal } \\
\text { pattern }\end{array}$} & \multicolumn{2}{|c|}{$\begin{array}{l}\text { Hetero- } \\
\text {-zygote } \\
\text { pattern }\end{array}$} & & & \\
\hline & 16 & 84.2 & 0 & 0 & \multirow{4}{*}{$\mathrm{x} 2=7.074 *$} & \multirow{4}{*}{0.04} & \multirow{4}{*}{$S$} \\
\hline $\begin{array}{l}\text { Partial } \\
\text { response } \mathrm{n}(\%)\end{array}$ & 3 & 15.8 & 2 & 100 & & & \\
\hline $\begin{array}{l}\text { No response } \\
\mathrm{n}(\%)\end{array}$ & 0 & 0 & 0 & 0 & & & \\
\hline Total n(\%) & 19 & 100 & 2 & 100 & & & \\
\hline
\end{tabular}

*Fisher Exact test

On comparing between FVL mutation results and response to treatment in lupus nephritis patients; a statistical significant difference was detected $(\mathrm{P}=$ 0.04). Accordingly, the presence of FVL mutation was observed to decrease the response of treatment in these patients as 19 out of 21 patients with lupus nephritis who had good or partial response showed normal pattern of Factor V, while the only two lupus nephritis patients that show heterozygous pattern of FVL were partially responsive to therapy.

\section{DISCUSSION}

Systemic Lupus Erythematosus is a chronic autoimmune inflammatory disease with a highly variable course of relapsing and remission. SLE can affect any part of the body and characterized by the production of multiple auto antibodies, mainly antinuclear (ANA) and antidsDNA antibodies ${ }^{(4)}$. SLE mainly occurs in females, frequently starting at their child bearing $\operatorname{period}^{(l)}$.

The diagnosis of SLE is often complex combining between both clinical and laboratory criteria. It's based on the presence of 4 out of 11 of the American College of Rheumatology (ACR) criteria for the classification of SLE (3) which include serositis, oral and nasal ulcers, arthritis, photosensitivity, hematological disorders, renal involvement, antinuclear antibodies, immunological phenomena, neurological disorders, malar rash and discoid rash ${ }^{(5)}$.

Renal involvement occurs in 50 to $75 \%$ of all SLE pediatric patients, and more than $90 \%$ of them will develop renal disease within the first 2 years after diagnosis ${ }^{(14)}$. SLE most commonly affects the glomerulus (lupus nephritis), with rare involvement of renal interstitium.

Renal biopsy should be performed for any suspicion of glomerulonephritis. The classification of glomerulonephritis in SLE ranges from Class I (minimal mesangial) to Class VI (advanced sclerosing lupus nephritis), and contain descriptions of the mesangial involvement, degree of renal involvement (focal or diffuse), and degree of involvement of the affected glomeruli (segmental or global) ${ }^{(15)}$.

So, the purpose of the current research was to study the presence of Factor V Leiden (G1691A) in SLE pediatric patients with and without complications and to investigate the association between the presence of this mutation and lupus complications mainly lupus nephritis in those patients. The results were correlated with patients laboratory data including hematological 
(Hemoglobin, total leucocytic count, platelet count, ESR), Immunological (C3, anticardiolipin IgG and IgM,lupus anticoagulant) and biochemical data (Serum creatinine, BUN, 24hrs urinary protein)

In this study, FVL was found in two patients in the patients' group, both of them were heterozygous pattern. One patient in the control group had FVL who was also heterozygous pattern. Both of the patients and control groups were compared regarding the prevalence of FVL mutation. Patients' group showed increase in the frequency of FVL mutation $(8 \%)$ in comparison to control group (4\%). However, it didn't reach a statistical significance. These results are in agreement with a study done on Hungarian SLE patients in which the frequency of the FVL mutation in SLE patients was 9-10\%. According to the same study, the FVL mutation could explain the tendency to have significantly high prevalence of cerebrovascular lesions, cardio valvular abnormalities, fetal losses and Raynaud syndrome than that found in patients without FVL ${ }^{(16)}$. Another study on Turkish population showed a higher FVL frequency $(12.7 \%)^{(17)}$.

The complications observed in patients group were further sub- classified into either: Lupus nephritis alone: representing $40 \%$ of complicated patients ranging from class II up to class $\mathrm{V}$ according to their renal biopsy in which class II accounted for $26 \%$, class III accounted for $47 \%$, class IV accounted for $11 \%$, class V accounted for $16 \%$ of patients with lupus nephrites. Lupus nephritis with other complications: represented $44 \%$. Complications other than lupus nephritis: represented $16 \%$. These complications include thrombosis, cerebrities, cardities, immune thrompocytopenic purpra and antiphospholipid antibody syndrome).

Both of the two patients in patients group with the heterozygous pattern of Factor $\mathrm{V}$ had lupus nephritis with other complications. So, regarding the prevalence of FVL in complicated SLE patients, FVL frequency was increased in patients with lupus nephritis combined with other complications (100\%) compared with patients with lupus nephritis alone $(0 \%)$ or with complications other than lupus nephritis $(0 \%)$. However, it didn't reach a statistical significance.

A retrospective study showed that the prevalence of FVL in a selected group with glomerular nephropathy was $6 \%$, consistent with the prevalence reported in other studies drawn from European and North American populations, and with a further large cohort study of patients with chronic kidney disease attending the same renal units. The same study suggested that the prevalence of FVL did not differ significantly in patients had glomerular nephropathy, either with or without complications mainly renal vein thrombosis, and the association would likely to occur by chance alone due to the relatively high prevalence of FVL in general population ${ }^{(18)}$. This was in contrast to a case report which had raised the possibility of association between APC resistance in the form of FVL, complications as renal vein thrombosis and membranous glomerulopathy. It also suggested that the coexistence of FVL and membranous glomerulopathy might serve as predisposing factors for the development of complications mainly renal vein thrombosis. The same case report showed that in minority of patients, glomerular nephropathy might possibly be secondary to hypercoagulable state leading to thrombotic complications and subsequent glomerulopathy ${ }^{(19)}$.

A large retrospective study showed that membranous histology as class $\mathrm{V}$ lupus nephritis and membranous nephropathy appears to increase the risk of nephrotic syndrome associated complications mainly the thrombotic complications ${ }^{(20)}$.

On studying the correlations between different lab parameters and the FVL mutation among patients' and control groups. The study showed that there was no significant findings could be obtained except for total leucocytic count with mean of $13.63 \pm 2.28$ in heterozygous pattern of FVL compared with $9.23 \pm 3.47$ in normal homozygous pattern, platelet count with mean of $126.6 \pm 7.63$ in heterozygous pattern compared with $268.9 \pm 111.3$ in normal homozygous pattern and serum creatinine level with mean of $0.433 \pm$ 0.057 in heterozygous pattern compared with 0.559 \pm 0.213 in normal homozygous pattern. No published data were available for comparing with these results. We suspect that some of these values might be affected by the disease remission and exacerbations.

The principle goal of treatment in lupus nephritis is to normalize renal function or, at least to prevent the progressive loss of renal function. Treatment of lupus nephritis differs according to the pathological lesion. It's important to treat the extra renal manifestations and other variables which might 
affect the kidneys ${ }^{(21)}$. The response of treatment in lupus nephritis is classified into good, partial and no response according to proteinuria, renal function tests and determination of SLE disease activity ${ }^{(22)}$.

The current study could find a significant correlation between the presence of the Factor $\mathrm{V}$ mutation and the response to treatment in lupus nephritis patients. Accordingly, the presence of FVL mutation was observed to decrease the response of treatment in these patients as $100 \%$ of patients with heterozygous pattern of Factor V showed partial response, compared with $84.2 \%$ of patients with normal homozygous pattern (wild type) that showed good response and $15.8 \%$ showed partial response. This was somewhat in partial agreement with a case report done on 2006 on a male patient with membranous glomerulopathy complicated with renal vein thrombosis and FVL mutation. This case showed persistence of nephrotic range proteinuria. Renal biopsy suggested membranous glomerulopathy six month after initiation of treatment with anticoagulant but he showed gradual improvement after a year and half of follow up and remained stable throughout the 5 years of follow up.

Limitations: Our study was limited because of the small sample size and relative short follow up period that may help explain the association between FVL and lupus complications mainly with lupus nephritis.

\section{CONCLUSION}

Complicated SLE patients had higher frequency for heterozygous patterns of FVL mutation compared to uncomplicated SLE patients despite it didn't reach a significant difference. FVL frequency was increased in patients with lupus nephritis combined with other complications compared to patients with lupus nephritis alone or with complications other than lupus nephritis. However, it didn't reach a statistical significance. The presence of FVL mutation was observed to decrease the response of treatment in patients with lupus nephritis.

\section{REFERENCES}

1. Danchenko N, Satia JA, Anthony MS (2006): "Epidemiology of systemic lupus erythematosus: a comparison of worldwide disease burden". Lupus, 15 (5): 308-318.
2. Lisnevskaia, L, Murphy G, Isenberg D (2014): "Systemic lupus erythematosus.", Lancet (London, England), 384 (9957): 18781888.

3. American College of Rheumatology (1997): American College of Rheumatology revised criteria for classification of systemic lupus erythematosus. Available at http://tinyurl.com/1997SLEcriteria

4. Bertsias G, Cervera R, Boumpas D (2012): Systemic lupus erythematosus: pathogenesis and clinical features. In: Bijlsma $\mathrm{J}$ (ed.): EULAR textbook on rheumatic diseases. London: BMJ Group.,Pp: 476-505.

5. Hochberg MC (1997): Updating the American College of Rheumatology revised criteria for the classification of systemic lupus erythematosus, Arthritis Rheum., 40:1725.

6. Edworthy SM (2005): Clinical Manifestations of Systemic Lupus Erythematosus. Harris ED, et al, eds. Kelley's Textbook of Rheumatology. 7th ed. Philadelphia, Pa: WB Saunders,Pp:1201-1224.

7. Bertoli AM, Fernandez M, McGwin G, JrAlarcon GS, Tan FK, Reveille JD (2006): Systemic lpuserythematosus in a multiethnic US colour. XXX111: clinical (corrected) features, course and outcome in patients with late-onset disease. Arthrities Rheum., 54:15801587.

8. Afeltra A, Vadacca M, Conti L (2005): "Thrombosis in systemic lupus erythematosus: congenital and acquired risk factors," Arthritis Care and Research, 53(3): 452-459.

9. Manger $K$, Manger $B$, Repp $R$ (2002): "Definition of risk factors for death, end stage renal disease, and thromboembolic events in a monocentric cohort of 338 patients with systemic lupus erythematosus," Annals of the Rheumatic Diseases, 61(12):1065-1070.

10. Les I, Ruiiz-Irastorza G, Kamashta MA (2012): Intensity and duration of anticoagulant theraby in phospholipid syndrome. Sem Throb Haemost., 38:339-347.

11. Kujovich JL (2011): Factor V Leiden thrombophilia. Genetics in Medicine, 13:1.

12. Dahlback B (2008): Advances in understanding pathogenic mechanisms of thrombophilic disorders, blood, 112:19-27. 
13. Mayo Clinic (2016): Activated Protein C Resistance V (APCRV). Mayo Medical Laboratories. Available at https://www.mayoclinic.org

14. Hiraki LT, Benseler SM, Tyrrell PN, Hebert D, Harvey E, Silverman ED (2008): Clinical and laboratory characteristics and long-term outcome of pediatric systemic lupus erythematosus: a longitudinal study. The Journal of pediatrics, 152(4): 550-556.

15. Hiraki LT, Benseler SM, Tyrrell PN (2008): Clinical and laboratory characteristics and long-term outcome of pediatric systemic lupus erythematosus: a longitudinal study. J Pediatr., 152:550-6.

16. Regéczy N, Lakos G, Balogh I, Ajzner E, Kiss E, Szegedi G (2000): The Leiden mutation of coagulation factor $\mathrm{V}$ in Hungarian SLE patients. Clin Appl Thromb Hemost., 6(1):41-5.

17. Topaloglu R, Akıerli C, Bakkaloglu A, Aydintug O, Ozen S, Besbas N, Ozcelik T (2001): Survey of factor $V$ leiden and prothrombin gene mutations in systemic lupus erythematosus. Clinical Rheumatology, 20(4): 259-261.

18. Irish AB (1997): The factor V Leiden mutation and risk of renal vein thrombosis in patients with nephrotic syndrome.Nephrology, dialysis, transplantation: official publication of the European Dialysis and Transplant AssociationEuropean Renal Association, 12(8): 1680-1683.
19. Elinav E, Rubinger D, Hiller N, Pizov G, Nadir E, Shapira Y, Heyman SN (2006): Renal vein thrombosis and membranous glomerulopathy in a patient homozygote for factor $\mathrm{V}$ Leiden mutation: a mere coincidence?. Thrombosis and HaemostasisStuttgart, 95(4): 740.

20. Bryce KA, Blatt NB, Fuh B, Zhao S, Lehman A, Blanchong C, Smoyer WE (2009): Epidemiology and risk factors for thromboembolic complications of childhood nephrotic syndrome: a Midwest Pediatric Nephrology Consortium (MWPNC) study. The Journal of pediatrics, 155(1): 105-110.

21. Dooley MA (2013): clinical and epidemiologic features of lupus nephritis. Wallace D.J, Hahn B.H, Dubois' Lupus Erythematosus and Related syndromes.8th edition Philadelphia, PA: Elsevier Saunders,Pp:438-54.

22. Gordon C, Jayne D, Pusey C (2009): European consensus statement on the terminology used in the management of lupus glomerulonephirities. Lupus, 18: 257-263. 